\title{
Susu Coklat Lebih Unggul dari Jus Tomat, dan Minuman Olahraga Komersial dalam Pemulihan Otot Pasca Latihan Interval training?
}

\author{
Santoso ${ }^{\bowtie}$, Hamidie Ronald Daniel Ray, Kuston Sultoni \\ Program Studi Ilmu Keolahragaan, Fakultas Pendidikan Olahraga dan Kesehatan, \\ Universitas Pendidikan Indonesia
}

\begin{tabular}{l} 
Kata Kunci: \\
Interval training, jus, latihan, \\
otot, pemulihan, susu \\
\hline
\end{tabular}

Interval training, jus, latihan, otot, pemulihan, susu

\begin{abstract}
Latihan fisik adalah aktifitas seseorang yang bertujuan untuk meningkatkan atau memelihara kebugaran tubuh.. Tujuan penelitian ini adalah untuk mengetahui apakah terdapat pengaruh yang signifikan mengkonsumsi minuman susu coklat, jus tomat dan minuman olahraga dalam pemulihan otot pasca latihan interval training. Metode yang digunakan dalam penelitian ini adalah eksperimen dengan desain post-test only group design. Sample berjumlah 10 orang yang dibagi ke dalam empat grup eskperimen minuman yang berbeda dengan sampel yang sama. Grup eksperimen 1 sebagai control dengan air putih, grup eksperimen 2 diberi susu coklat, grup ke 3 diberi jus tomat, dan grup 4 diberi minumn olahraga. Instrumen yang digunakan dalam penelitian ini adalah Rast Test dan test kadar gula darah. Pada saat posttest semua sampel mengkonsumsi minuman sesuai dengan perlakuan setelah melakukan interval training. Analisis data menggunakan One-Way ANOVA dan uji Post Hoc-Tukey HSD untuk melihat pengaruh dan perbandingan antar kelompok. Hasil dari penelitian menunjukkan bahwa terdapat perbedaan yang signifikan rata-rata pemulihan otot dari berbagai instrument dibuktikan dengan nilai (sig) $0.00<0,05$ dengan grup susu coklat memiliki pemulihan otot yang paling baik. Dapat disimpulkan bahwa terdapat pengaruh signifikan mengkonsumsi susu coklat dalam pemulihan otot pasca latihan interval training.
\end{abstract}

\begin{abstract}
The purpose of this research is to find out whether there are significant effects of consuming chocolate milk drink, tomato juice and sports drinks in muscle recovery post workout interval training. The methods used in this study is an experiment with the design of post-test only group design. The number of sample was 10 who were divided into four groups of different drinks experiment with the same sample. Experimental group 1 as control with mineral water, experimental group 2 is given a milk chocolate, 3rd group was given a tomato juice, and group 4 were given sport drink. The instruments used in this research is the Rast Test and sugar blood test levels. When doing post-test all sample consumes the beverage in accordance with treatment after doing interval training. The data then analyzed using one-way ANOVA and test Post Hoc-Tukey HSD to see the influences and comparisons between groups. The result of the research shows that there is a significant difference in average muscle recovery from various instruments evidenced by value (sig)
\end{abstract}


with $0.050 .00<$ chocolate milk group have the most muscle recovery either. Therefore be concluded that there is a significant influence of consuming chocolate milk post workout muscle recovery in interval training.

(C) 2019 Universitas Pendidikan Indonesia 


\section{PENDAHULUAN}

Interval training mengacu terhadap intermittent exercise yang melibatkan pada periode latihan diikuti oleh periode pemulihan, yang memungkinkan siapa pun dapat meningkatkan intensitas latihan tersebut (Ramos et al., 2017). Latihan fisik menggunakan metode latihan interval training dapat meningkatkan $\mathrm{VO} 2 \mathrm{max}$ secara signifikan menggunakan intesitas latihan yang tinggi ( $70 \%$ dari kemampuan maksimal) yang diselingi oleh istirahat (2-3 menit) membuat peningkatan VO2max lebih signifikan (Busyairi \& Ray, 2018). Keuntungan yang diperoleh dengan menggunakan metode latihan interval jika dibandingkan dengan metode lainnya latihan interval training karena rangkaian aktifitas fisik yang sistematis pada sistem latihan yang diselingi oleh interval-interval yang berupa masa-masa istirahat (Busyairi \& Ray, 2018). Tujuannya yaitu untuk meningkatkan kemampuan ergosistem tubuh melalui suatu proses yang dilakukan secara cermat dan berulang dengan meningkatkan beban. Interval training dilakukan dengan lambat akan tetapi jarak lebih jauh dengan beberapa ketentuan yang harus lakukan seperti lama latihan $60 \mathrm{dtk}$ s.d 3 menit, intensitas latihan max $10 \%-70 \%$, ulangan lari 10 s.d 20 kali, dan intirahat 3 s.d 5 menit (MacInnis \& Gibala, 2017). Interval training yang digunakan peneliti dengan repetisi 3 kali, jarak 400 meter, waktu tempuh 80 detik, dan istirahat 3 menit.

Dalam melakukan olahraga dengan intensitas atau durasi yang cukup lama diperlukan sebuah proses atau tindakan recovery atau pemulihan yang cepat agar seseorang dapat melakukan latihan pada tahan selanjutnya dengan kondisi pemulihan yang sudah maksimal, oleh karena itu tindakan pemulihan sangat amat penting diperlukan untuk mengembalikan kesempatan pada tubuh dalam mengembalikan tenaga yang telah pergunakan sehingga dapat dipergunakn kembali (Rashedi \& Nussbaum, 2017). Aktivitas pada fisik akan menyebabkan peningkatan tingkat metabolisme dan produksi panas yang mengakibatkan hilangnya air dan elektrolit dan deplesi glikogen di hati dan otot (Maughan \& Shirreffs, 2008). Produk yang dapat membantu pemulihan saat ini sangat mudah dan banyak untuk kita jumpai dari makanan atau minuman. Diantaranya adalah susu coklat, jus tomat dan minuman olahraga komersial. Beberapa penelitian menyebutkan susu coklat adalah minuman yang bermanfaat dan potensial bagi atlet untuk face recovery (pemulihan) setelah melakukan pada aktifitas olahraga dan juga mengandung sumber antioksidan, hal ini dipercaya karena karbohidrat dan protein yang tinggi dalam susu coklat dan membantu mengganti nutrisi yang hilang (Gilson et al., 2010).

Minuman olahraga (sport drink) merupakan minuman yang didalamnya terdapat pada air, zat gizi, dan zat terlarut untuk mendukung pada ergogenic serta digunakan untuk mengganti air dan elektrolit yang hilang saat berkeringat selama olahraga (Shirreffs, 2001). Dibandingkan dengan air biasa, minuman yang mengandung karbohidrat dan garam (elektrolit) dapat meningkatkan kinerja ketika dikonsumsi sebelum atau selama exercise intensitas tinggi yang berlangsung setidaknya satu jam (Rismayanthi, 2014). Gula yang terdapat pada minuman sport drink berguna membantu menjaga level glukosa dalam darah dan memberikan suplai energy pada otot (Shirreffs \& Sawka, 2011). Minuman sport drink dapat berfungsi untuk mempertahankan cairan dan garam tubuh serta memberikan energi karbohidrat ketika melakukan aktivitas

Jus tomat mengandung banyak vitamin C dan vitamin A serta likopen sebagai antioksidan (Lubis \& Siregar, 2017). Likopen diketahui memiliki kemampuan yaitu sebagai antioksidan yang berfungsi mengikat electron yang tidak berpasangan dari radikal bebas sehingga mempertahankan proses pembentukan ATP secara aerobic di mitokondria yang mengakibatkan denyut nadi pemulihan lebih cepat (Jabari, Jafari, Dehnad, \& Shahidi, 2018).

Berdasarkan latar belakang dan analisis masalah yang telah diungkapkan diatas tujuan peneliti bertujuan untuk meneliti tentang pengaruh susu coklat, jus tomat, dan minuman 
olahraga komersial dalam pemulihan otot pasca latihan interval traning.

\section{METODE}

\section{Disain Penelitian}

Dalam penelitian ini menggunakan metode pre-experimental. Dengan bentuk desain post-test only control (Figure, n.d.).

Partisipan

Populasi penelitian ini adalah kelompok remaja usia 19-22 tahun yang terdaftar sebagai mahasiswa olahraga disalah satu Universitas Negeri di Bandung. Dengan sampel berjumlah 10 orang menggunakan teknik pengambilan sampel yaitu Purposive sampling. Karakteristik Sampel dalam penelitian ini laki - laki berusia $19-22$ tahun, berbadan sehat dan tidak cacat fisik.

\section{Eksperimen}

Penelitian dibagi mejadi dua sesi dimana masing-masing pada sesi pelaksanaan berjarak sekitar 1 minggu. Sampel akan melakukan latihan interval training berupa lari dengan jarak 400 meter dengan waktu target tempuh 80 detik dan di selingi istirahat 3 menit. Segera setelah test selesai, sampel segera dilanjutkan dengan pemberian pada kelompok hari pertama dengan minuman control yaitu air putih $250 \mathrm{ml}$, kelompok hari kedua dengan susu coklat $250 \mathrm{ml}$, kelompok hari ketiga dengan jus tomat $250 \mathrm{ml}$, dan hari keempat dengan minuman olahraga komersial $250 \mathrm{ml}$. Sampel penelitian lalu diistirahatkan selama 15 menit setelah diberikan minuman. Setelah itu sampel melakukan Running-based Anaerob Test (RAST) disesi pertama dan dilakukan pemberian test kadar gula darah di sesi kedua. Post test dilakukan pada hari yang berbeda, satu hari sebelum melakukan tes sampel diberitahu agar melakukan puasa selama 8 jam (jam .09.0015.00) agar semua sampel melakukan tes dalam kondisi yang sama.

Instrumen Penelitian

Intsrumen penelitian munggunakan RAST test (Running based Anaerobic Sprint Test) (Lum, Tan, Pang, \& Barbosa, 2016). untuk mengetahui Indeks Kelelahan, dan untuk penentuan kadar gula darah sampel diukur kadar gula darahnya menggunakan auto check dan strips glukosa. RAST test bertujuan untuk mengukur kemampuan daya tahan anaerobic dan mengetahui indeks kelelahan. Indicator yang di gunakan untuk menilai kelelahan otot adalah fatigue index / indeks kelelahan.

Nilai indeks kelelahan $\leq 10$ mengindikasikan kemampuan atlet/subjek dalam mempertahankan performa anaerobic nya (termasuk kategori tidak lelah) . Nilai indeks kelelahan $\geq 10$ merupakan indikasi bahwa atlet/subjek perlu meningkatkan performa anaerobiknya dan juga meningkatkan toleransi terhadap asam laktat (termasuk kategori lelah) (Mackenzie, 2008).

Analisis Data

Data dianalisis menggunakan Uji Normalitas, One-Way ANOVA (Analisis of Variance) dan uji Post Hoc-Tukey HSD. Tujuan dari pengolahan data tersebut adalah agar data yang sudah terkumpul dapat memiliki makna dan dapat dijadikan patokan untuk menjawab rumusan masalah dan menarik kesimpulan. Kemudian, proses pengolahan data hasil dari masing-masing variabel yaitu menggunakan bantuan program Statistical Product for Social Science (SPSS).

Selanjutnya data yang berskala kontinyu seperti indeks kelelahan dan sebagainya dinyatakan sebagai rerata dan simpang baku apabila berdistribusi normal atau median dan rentang apabila berdistribusi tidak normal. Fungsi variabel bebas adalah untuk mewakili pada kelompok-kelompok yang akan diteliti. Sedangkan uji Post Hoc-Tukey HSD adalah pengujian perbandingan untuk menentukan apakah rata-rata kelompok atau lebih berbeda secara signifikan dalam jumlah analisis varian. Tingkat kepercayaan analisis data pada penelitian ini adalah $95 \%$, sehingga nilai $\alpha$ untuk penelitian ini yaitu 0,05 .

\section{HASIL DAN PEMBAHASAN}

Hasil

Pada penelitian ini peneliti menggunakan Rast Test dengan hasil tiap minuman yang sudah dirata-rata pada hasil tiap minuman. 
Dapat dilihat pada (Gambar 1) menunjukan hasil rata-rata dengan nilai air putih 8.9 , susu coklat 3.34 , minuman olahraga 5.18, dan jus tomat 6.07. Dari gambar tersebut dapat dilihat bahwa sampel yang diberi susu coklat menunjukan nilai indeks kelelahan yg rendah yaitu dengan nilai 3.34. Dilihat untuk nilai indeks kelelahan tertinggi terdapat pada minuman air putih dengan nilai 8.9.

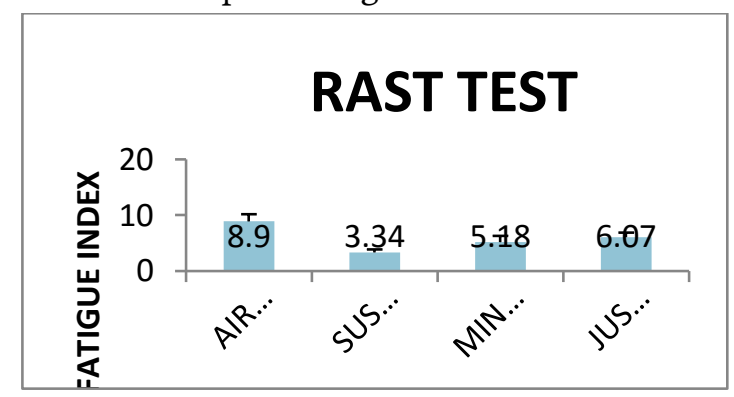

Gambar 1. Nilai Rata-rata Indeks Kelelahan

Dapat dilihat dari (Tabel 1) diperoleh tanda (*) pada kolom mean difference yang menunjukan nilai signifikan $<0,05$. Kecuali dengan minuman jus tomat dengan minuman olahraga yang $p=0260>0,05$. H0 tidak terdapat perbedaan yang signifikan Indeks Kelelahan pada minuman susu coklat, jus tomat, dan minuman olahraga terhadap pemulihan otot pasca interval training $\mathrm{H} 1$ terdapat perbedaan yang signifikan indeks kelelahan pada minuman susu coklat, jus tomat, dan minuman olahraga terhadap pemulihan otot pasca interval training. Jika probalitas atau signifikansi $>0.05$, maka H0 diterima, dan Jika probalitas atau signifikansi < 0.05 , maka H0 ditolak dengan demikian bias digambarkan bahwa air putih dengan susu coklat dengan angka sig. sebesar $0.00<0.05$ maka $\mathrm{H} 0$ ditolak. Air putih dengan jus tomat dengan angka sig. sebesar $0.00<0.05$ maka H0 ditolak. Air putih dengan minuman olahraga dengan angka sig. sebesar $0.00<0.05$ maka H0 ditolak. Susu coklat dengan jus tomat dengan angka sig. sebesar $0.00<0.05$ maka H0 ditolak. Susu coklat dengan minuman olahraga dengan angka sig. sebesar $0.01<0.05$ maka H0 ditolak. Jus tomat dengan minuman olahraga dengan angka sig. Sebesar $0.260>0.05$ maka H0 diterima. Dapat disimpukan bahwa sampel yang diberi susu coklat lebih baik dibandingkan air putih, jus tomat, dan minuman olahraga dengan hasil nilai susu coklat lebih rendah pada indeks kelelahan.

Tabel 1 . Uji Pos Hoc-Tukey HSD Rast Test

\begin{tabular}{|c|c|r|r|r|}
\hline Metode & Metode & $\begin{array}{c}\text { Mean } \\
\text { Difference }\end{array}$ & Std. Error & Sig. \\
\hline \multirow{3}{*}{ Air Putih } & Susu Coklat & $5.44970^{*}$ & .43513 & .000 \\
\cline { 2 - 5 } & Jus Tomat & $2.81820^{*}$ & .43513 & .000 \\
\cline { 2 - 5 } & Minuman Olahraga & $3.63070^{*}$ & .43513 & .000 \\
\hline \multirow{3}{*}{ Susu Coklat } & Air Putih & $-5.44970^{*}$ & .43513 & .000 \\
\cline { 2 - 5 } & Jus Tomat & $-2.63150^{*}$ & .43513 & .000 \\
\cline { 2 - 5 } & Minuman Olahraga & $-1.81900^{*}$ & .43513 & .001 \\
\hline \multirow{3}{*}{ Jus Tomat } & Air Putih & $-2.81820^{*}$ & .43513 & .000 \\
\cline { 2 - 5 } & Susu Coklat & $2.63150^{*}$ & .43513 & .000 \\
\cline { 2 - 5 } & Minuman Olahraga & .81250 & .43513 & .260 \\
\hline
\end{tabular}

Gambar 2 menunjukan hasil rata-rata dengan nilai air putih 1.8 , susu coklat 12.2 , minuman olahraga 4.4, dan jus tomat 2.5. Dari gambar tersebut dapat dilihat bahwa sampel yang diberi air putih menunjukan nilai indeks kelelahan yg rendah yaitu dengan nilai 1.8 . Dilihat untuk nilai indeks kelelahan tertinggi terdapat pada minuman susu coklat dengan nilai 12.2. 


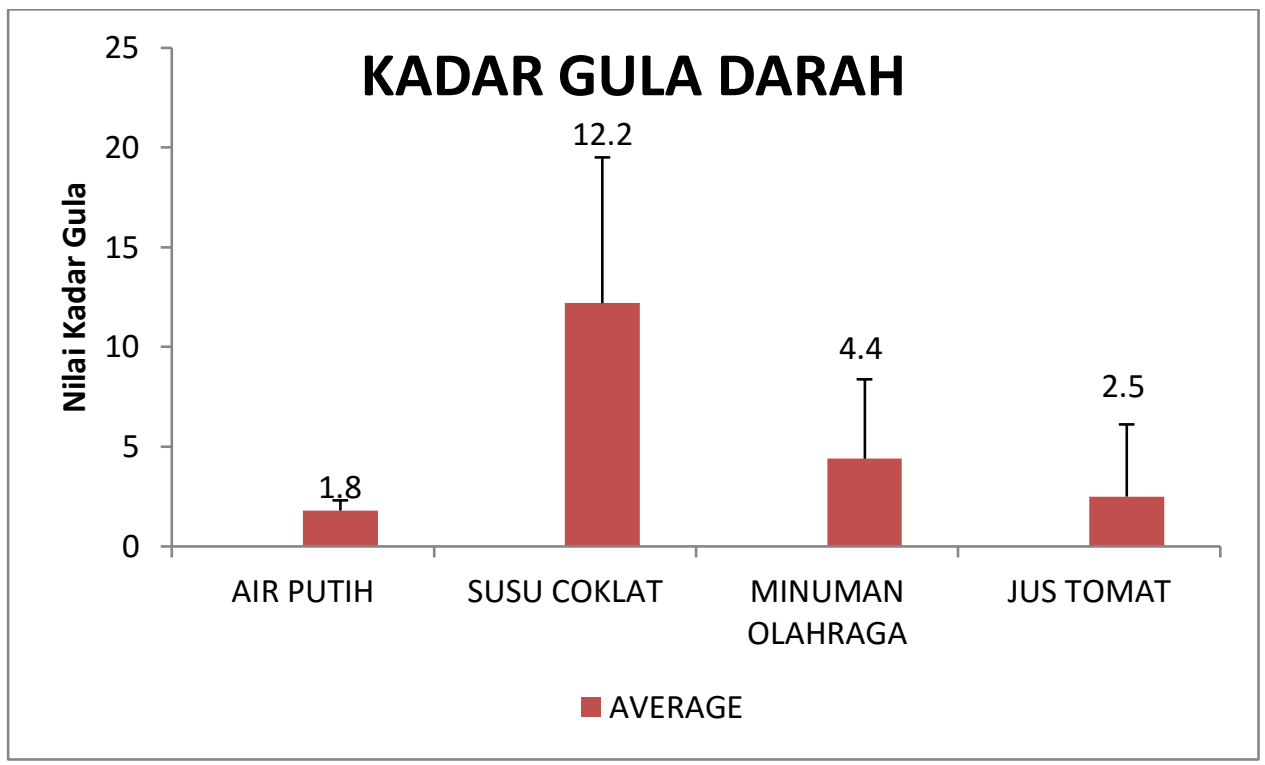

Dapat dilihat dari (Tabel 2) diperoleh tanda $\left(^{*}\right)$ pada kolom mean difference yang menunjukan nilai signifikan $<0,05$. H0 tidak terdapat perbedaan yang signifikan kadar gula darah pada minuman susu coklat, jus tomat, dan minuman olahraga terhadap pemulihan otot pasca interval training. H1 terdapat perbedaan yang signifikan kadar gula darah pada minuman susu coklat, jus tomat, dan minuman olahraga terhadap pemulihan otot pasca interval training. Jika probalitas atau signifikansi $>0.05$, Maka H0 diterima. Jika probalitas atau signifikansi < 0.05 , Maka H0 ditolak. Air putih dengan susu coklat dengan angka sig. sebesar $0.19<0.05$ maka H0 ditolak. Air putih dengan jus tomat dengan angka sig. sebesar $0.997<0.05$ maka H0 diterima. Air putih dengan minuman olahraga dengan angka sig. sebesar $0.865<0.05$ maka H0 diterima. Susu coklat dengan jus tomat dengan angka sig. sebesar $0.031<0.05$ maka H0 ditolak. Susu coklat dengan minuman olahraga dengan angka sig. sebesar $0.111<0.05$ maka H0 diterima. Jus tomat dengan minuman olahraga dengan angka sig. Sebesar $0.941>0.05$ maka H0 diterima. Dapat disimpukan bahwa sampel yang diberi susu coklat lebih baik dibandingkan air putih, jus tomat, dan minuman olahraga dengan hasil nilai susu coklat tinggi pada nilai kadar gula darah.

Tabel 2. Uji Pos Hoc-Tukey HSD Kadar Gula Darah

\begin{tabular}{|c|c|r|r|r|}
\hline Metode & Metode & $\begin{array}{c}\text { Mean } \\
\text { Difference }\end{array}$ & Std. Error & \multicolumn{1}{c|}{ Sig. } \\
\hline \multirow{4}{*}{ Air Putih } & Susu Coklat & $-10.400^{*}$ & 3.353 & .019 \\
\cline { 2 - 5 } & Jus Tomat & -.700 & 3.353 & .997 \\
\cline { 2 - 5 } & Minuman Olahraga & -2.600 & 3.353 & .865 \\
\hline \multirow{3}{*}{ Susu Coklat } & Air Putih & $10.400^{*}$ & 3.353 & .019 \\
\cline { 2 - 5 } & Jus Tomat & $9.700^{*}$ & 3.353 & .031 \\
\cline { 2 - 5 } & Minuman Olahraga & 7.800 & 3.353 & .111 \\
\hline \multirow{3}{*}{ Jus Tomat } & Air Putih & .700 & 3.353 & .997 \\
\cline { 2 - 5 } & Susu Coklat & $-9.700^{*}$ & 3.353 & .031 \\
\cline { 2 - 5 } & Minuman Olahraga & -1.900 & 3.353 & .941 \\
\hline
\end{tabular}


Dari hasil penelitian diatas dapat disimpulkan bahwa terdapat pengaruh yang signifikan meminum susu coklat pasca latihan interval training dalam pemulihan otot, dan tidak berpengaruh signifikan mengkonsumsi minuman olahraga, dan jus tomat terhadap pemulihan otot. Hasil penelitian menunjukkan terdapat perbedaan nilai indeks kelelahan yang bermakna antara kelompok minuman olahraga dan kelompok kontrol. Minuman olahraga menunjukkan nilai indeks kelelahan yang lebih besar dibanding dengan kelompok kontrol. Hasil penelitian tersebut berbeda dengan penelitian oleh Isadora Lessa Moreno yang menyebutkan bahwa minuman isotonik dapat mempercepat masa pemulihan ditunjukkan dengan penyembuhan yang lebih cepat pada variabilitas detak jantung (heart rate variability) (Moreno et al., 2013). Kandungan yang terdapat pada susu cokla yang begitu kompleks mengakibatkan susu coklat lebih unggul dibanding minuman lainnya. Terutama kandungan karbohidrat yang lebih banyak di susu coklat karena karbohidrat yang diubah menjadi glukosa dalam tubuh dipecah untuk menyediakan energy pada sel atau jaringan dan dapat disimpan sebagai simpanan energy dalam sel (Pocock, Richards, Richards, \& Richards, 2013).

Efek dari konsumsi susu coklat setelah latihan ketahanan dapat memberi sinyal molekul pergantian protein otot rangka, kinetika leusin, dan ukuran kinerja menunjukkan manfaat susu yang unik dibandingkan dengan minuman yang hanya mengandung karbohidrat (Lunn et al., 2012). Susu coklat yang diberikan setelah pemulihan dapat meningkatkan kinerja percobaan waktu berikutnya pada pengendara sepeda terlatih lebih efektif daripada minuman lainya. Ini mungkin disebabkan oleh laju resintesis glikogen otot yang lebih cepat dari susu coklat dibandingkan minuman lainnya (Ferguson-Stegall et al., 2010). Pemulihan setelah melakukan latihan yang intens sangat penting untuk mengoptimalkan pada kinerja selanjutnya. Suplemen nutrisi atau minuman yang mengandung banyak karbohidrat dan banyaknya protein adalah konstituen utama atau hal penting dalam olahraga untuk pemulihan (Flores et al., 2011). Karbohidrat dalam bentuk glukosa adalah bahan bakar yang lebih disukai untuk kerja otot. Pada saat berolahraga terutama olahraga dengan intensitas moderat-tinggi, kebutuhan energi bagi tubuh dapat terpenuhi melalui simpanan glikogen, terutama glikogen otot serta melalui simpanan glukosa yang terdapat di dalam aliran darah dimana ketersediaan glukosa di dalam aliran darah ini dapat dibantu oleh glikogen hati agar levelnya tetap berada pada keadaan normal (Pocock et al., 2013).

Perbandingan nilai indeks kelelahan antara kelompok susu cokelat, jus tomat dan kelompok minuman olahraga berdasarkan uji statistik menunjukkan perbedaan yang bermakna. Kelompok susu cokelat terdapat nilai indeks kelelahan yang lebih kecil dibanding pada kelompok minuman olahraga sehingga dapat disimpulkan bahwa pemberian susu cokelat lebih mempercepat masa pemulihan pasca latihan pada program interval training dibanding dengan pemberian minuman jus tomat, dan olahraga komersial. Penelitian mengenai perbandingan antara pemberian pada susu cokelat dan minuman olahraga pada performa anaerob memang masih terbatas, namun penelitian yang dilakukan oleh Jason $\mathrm{R}$. Karp yang meneliti tentang pengaruh susu cokelat sebagai minuman pemulihan pasca latihan pada latihan daya tahan aerob menunjukkan bahwa susu cokelat merupakan minuman yang lebih efektif dibandingkan dengan minuman pengganti cairan komersial dan minuman pengganti karbohidrat (Karp \& Johnston, 2006). Hasil penelitian ini menunjukkan bahwa baik pada latihan aerob dan anaerob, susu cokelat merupakan minuman pemulihan yang lebih baik dibandingkan dengan minuman olahraga komersial.

Penelitian sebelumnya pada perbandingan pada jus tomat dan minuman air kelapa menunjukan hasil yang menyatakan bahwa kondisi tubuh terasa lebih bugar dan cepat pulih pada saat setelah latihan meminum jus tomat dibandingkan dengan pemberian air kelapa 
muda. Berkaitan dengan tersebut pemberian jus tomat yang tigi akan vitamin $\mathrm{A}$, vitamin $\mathrm{C}$, dan likopen dapat mengikat electron yang tidak berpasangan dari redikal bebas sehingga mempertahankan pada proses pembentukan ATP secara aerob dimitokondria. Penelitian tersebut memberikan pernyataan bahwasaanya hal dapat mengakibatkan denyut pada nadi pemulihan lebih cepat tercapai dibandingkan pada pemberian air kelapa (Lubis \& Siregar, 2017).

Maka dari itu terdapat pengaruh yang signifikan keadaan indeks kelelahan pada pemberian jenis minuman Susu Coklat, Jus Tomat, dan Minuman Olahraga pada sempel. Hal ini bisa terjadi karena di lihat dari kandungannya, jenis minuman susu coklat, jus tomat, dan minuman olahraga mengandung karbohidrat, protein, kalium, natrium, glukosa yang bisa menunda kelelahan pada otot dan mempercepat pemulihan dalam otot.

\section{KESIMPULAN}

Berdasarkan pada hasil analisis data dapat disimpulkan bahwa, terdapat pengaruh signifikan mengkonsumsi susu coklat dalam pemulihan otot pasca latihan interval training.

\section{DAFTAR PUSTAKA}

Busyairi, B., \& Ray, H. R. D. (2018). Perbandingan Metode Interval Training dan Continuous Run terhadap Peningkatan Vo2max. Jurnal Terapan Ilmu Keolahragaan, $3(1), \quad 76$. https://doi.org/10.17509/jtikor.v3i1.1012 8

Ferguson-Stegall, L., McCleave, E. L., Doerner, P. G., Ding, Z., Wang, B., Dessard, B., ... Ivy, J. L. (2010). Effects of Chocolate Milk Supplementation on Recovery from Cycling Exercise and Subsequent Time Trial Performance. Medicine \& Science in Sports \& Exercise, 42, 760. https://doi.org/10.1249/01.mss.00003862 04.90806 .51

Figure, S. (n.d.). No Title No Title_2015. https://doi.org/10.15713/ins.mmj.3

Flores, H. A., Shull, R. A., Schmitt, R., Randle, C., Sullivan, K., Blazer, C., ... Astorino, T.
A. (2011). Efficacy of Chocolate Soy Milk Ingestion on Supramaximal Exercise Performance. Medicine \& Science in Sports \& Exercise, 43(Suppl 1), 585. https://doi.org/10.1249/01.mss.00004016 13.48260 .76

Gilson, S. F., Saunders, M. J., Moran, C. W., Moore, R. W., Womack, C. J., \& Todd, M. K. (2010). Effects of chocolate milk consumption on markers of muscle recovery following soccer training: a randomized cross-over study. Journal of the International Society of Sports Nutrition, $7(1), \quad 19$. https://doi.org/10.1186/1550-2783-7-19

Jabari, S. S., Jafari, S. M., Dehnad, D., \& Shahidi, S. A. (2018). Changes in lycopene content and quality of tomato juice during thermal processing by a nanofluid heating medium. Journal of Food Engineering, 230, $1-7$. https://doi.org/10.1016/j.jfoodeng.2018. 02.020

Karp, J. R., \& Johnston, J. D. (2006). Chocolate milk as a post -exercise recovery aid. International Journal of Sport Nutrition and Exercise Metabolism, 16(23), 78-91. https://doi.org/10.1097/00005768200405001-00600

Lubis, R. F., \& Siregar, N. S. (2017). Pengaruh Pemberian Semangka Terhadap Denyut Nadi Pemulihan Setelah Melakukan Aktivitas Fisik. Sains Olahraga: Jurnal Ilmiah Ilmu Keolahragaan, 1(1).

Lum, D., Tan, F., Pang, J., \& Barbosa, T. M. (2016). Effects of intermittent sprint and plyometric training on endurance running performance. Journal of Sport and Health Science, (August). https://doi.org/10.1016/j.jshs.2016.08.00 5

Lunn, W. R., Pasiakos, S. M., Colletto, M. R., Karfonta, K. E., Carbone, J. W., Anderson, J. M., \& Rodriguez, N. R. (2012). Chocolate milk and endurance exercise recovery: Protein balance, glycogen, and performance. Medicine and Science in Sports and Exercise, 44(4), 682691. https://doi.org/10.1249/MSS.0b013e318 2364162

MacInnis, M. J., \& Gibala, M. J. (2017). Physiological adaptations to interval training and the role of exercise intensity. The Journal of Physiology, 595(9), 29152930. 
Mackenzie, B. (2008). 101 Tests D'Évaluations.

Maughan, R. J., \& Shirreffs, S. M. (2008). Development of individual hydration strategies for athletes. International Journal of Sport Nutrition and Exercise Metabolism, 18(5), 457-472.

Moreno, I. L., Pastre, C. M., Ferreira, C., de Abreu, L. C., Valenti, V. E., \& Vanderlei, L. C. M. (2013). Effects of an isotonic beverage on autonomic regulation during and after exercise. Journal of the International Society of Sports Nutrition, 10(1), 2.

Pocock, G., Richards, C. D., Richards, D., \& Richards, D. A. (2013). Human physiology. Oxford university press.

Ramos, J. S., Dalleck, L. C., Borrani, F., Beetham, K. S., Mielke, G. I., Dias, K. A., ... Coombes, J. S. (2017). High-intensity interval training and cardiac autonomic control in individuals with metabolic syndrome: A randomised trial. International Journal of Cardiology, 245, 245-252.

Rashedi, E., \& Nussbaum, M. A. (2017). Quantifying the history dependency of muscle recovery from a fatiguing intermittent task. Journal of Biomechanics, 51 , 26-31. https://doi.org/10.1016/j.jbiomech.2016. 11.061

Rismayanthi, C. (2014). Hubungan Antara Status Hidrasi dan Konsumsi cairan. Yogyayakarta. Fakultas Ilmu Keolahragaan.

Shirreffs, S. M. (2001). The optimal sports drink.

Shirreffs, S. M., \& Sawka, M. N. (2011). Fluid and electrolyte needs for training, competition, and recovery. Journal of Sports Sciences, 29(SUPPL. 1). https://doi.org/10.1080/02640414.2011.6 14269

Busyairi, B., \& Ray, H. R. D. (2018). Perbandingan Metode Interval Training dan Continuous Run terhadap Peningkatan Vo2max. Jurnal Terapan Ilmu Keolahragaan, $\quad 3(1), \quad 76$. https://doi.org/10.17509/jtikor.v3i1.1012 8

Ferguson-Stegall, L., McCleave, E. L., Doerner, P. G., Ding, Z., Wang, B., Dessard, B., ... Ivy, J. L. (2010). Effects of Chocolate Milk Supplementation on Recovery from Cycling Exercise and Subsequent Time Trial Performance. Medicine \& Science in
Sports \& Exercise, 42, 760. https://doi.org/10.1249/01.mss.00003862 04.90806 .51

Figure, S. (n.d.). No Title No Title_2015. https://doi.org/10.15713/ins.mmj.3

Flores, H. A., Shull, R. A., Schmitt, R., Randle, C., Sullivan, K., Blazer, C., ... Astorino, T. A. (2011). Efficacy of Chocolate Soy Milk Ingestion on Supramaximal Exercise Performance. Medicine \& Science in Sports \& Exercise, 43(Suppl 1), 585. https://doi.org/10.1249/01.mss.00004016 13.48260 .76

Gilson, S. F., Saunders, M. J., Moran, C. W., Moore, R. W., Womack, C. J., \& Todd, M. K. (2010). Effects of chocolate milk consumption on markers of muscle recovery following soccer training: a randomized cross-over study. Journal of the International Society of Sports Nutrition, $7(1), \quad 19$. https://doi.org/10.1186/1550-2783-7-19

Jabari, S. S., Jafari, S. M., Dehnad, D., \& Shahidi, S. A. (2018). Changes in lycopene content and quality of tomato juice during thermal processing by a nanofluid heating medium. Journal of Food Engineering, 230 , $1-7$. https://doi.org/10.1016/j.jfoodeng.2018. 02.020

Karp, J. R., \& Johnston, J. D. (2006). Chocolate milk as a post -exercise recovery aid. International Journal of Sport Nutrition and Exercise Metabolism, 16(23), 78-91. https://doi.org/10.1097/00005768200405001-00600

Lubis, R. F., \& Siregar, N. S. (2017). Pengaruh Pemberian Semangka Terhadap Denyut Nadi Pemulihan Setelah Melakukan Aktivitas Fisik. Sains Olahraga: Jurnal Ilmiah Ilmu Keolahragaan, 1(1).

Lum, D., Tan, F., Pang, J., \& Barbosa, T. M. (2016). Effects of intermittent sprint and plyometric training on endurance running performance. Journal of Sport and Health Science, (August). https://doi.org/10.1016/j.jshs.2016.08.00 5

Lunn, W. R., Pasiakos, S. M., Colletto, M. R., Karfonta, K. E., Carbone, J. W., Anderson, J. M., \& Rodriguez, N. R. (2012). Chocolate milk and endurance exercise recovery: Protein balance, glycogen, and performance. Medicine and Science in Sports and Exercise, 44(4), 682691. 
https://doi.org/10.1249/MSS.0b013e318 2364162

MacInnis, M. J., \& Gibala, M. J. (2017). Physiological adaptations to interval training and the role of exercise intensity. The Journal of Physiology, 595(9), 29152930.

Mackenzie, B. (2008). 101 Tests D'Évaluations.

Maughan, R. J., \& Shirreffs, S. M. (2008). Development of individual hydration strategies for athletes. International Journal of Sport Nutrition and Exercise Metabolism, 18(5), 457-472.

Moreno, I. L., Pastre, C. M., Ferreira, C., de Abreu, L. C., Valenti, V. E., \& Vanderlei, L. C. M. (2013). Effects of an isotonic beverage on autonomic regulation during and after exercise. Journal of the International Society of Sports Nutrition, 10(1), 2.

Pocock, G., Richards, C. D., Richards, D., \& Richards, D. A. (2013). Human physiology. Oxford university press.

Ramos, J. S., Dalleck, L. C., Borrani, F., Beetham, K. S., Mielke, G. I., Dias, K. A.,
... Coombes, J. S. (2017). High-intensity interval training and cardiac autonomic control in individuals with metabolic syndrome: A randomised trial. International Journal of Cardiology, 245, 245-252.

Rashedi, E., \& Nussbaum, M. A. (2017). Quantifying the history dependency of muscle recovery from a fatiguing intermittent task. Journal of Biomechanics, 51, 26-31. https://doi.org/10.1016/j.jbiomech.2016. 11.061

Rismayanthi, C. (2014). Hubungan Antara Status Hidrasi dan Konsumsi cairan. Yogyayakarta. Fakultas Ilmu Keolahragaan.

Shirreffs, S. M. (2001). The optimal sports drink.

Shirreffs, S. M., \& Sawka, M. N. (2011). Fluid and electrolyte needs for training, competition, and recovery. Journal of Sports Sciences, 29(SUPPL. 1). https://doi.org/10.1080/02640414.2011.6 14269 